\title{
Téoros
}

Revue de recherche en tourisme

\section{Adventure Travel in Western Canada: Strategic Management Issues and Actions}

\section{Peter W. Williams, J. Kent Stewart et Bernard Campbell}

Volume 13, numéro 3, automne 1994

Le tourisme d'aventure : vers la maturité ?

URI : https://id.erudit.org/iderudit/1077110ar

DOI : https://doi.org/10.7202/1077110ar

Aller au sommaire du numéro

Éditeur(s)

Université du Québec à Montréal

ISSN

0712-8657 (imprimé)

1923-2705 (numérique)

Découvrir la revue

Citer cet article

Williams, P. W., Stewart, J. K. \& Campbell, B. (1994). Adventure Travel in Western Canada: Strategic Management Issues and Actions. Téoros, 13(3),

23-28. https://doi.org/10.7202/1077110ar d'utilisation que vous pouvez consulter en ligne. 


\section{Adventure Travel in Western Canada: Strategic Management Issues and Actions}

Peter W. Williams, J. Kent Stewart and Bernard Campbell*

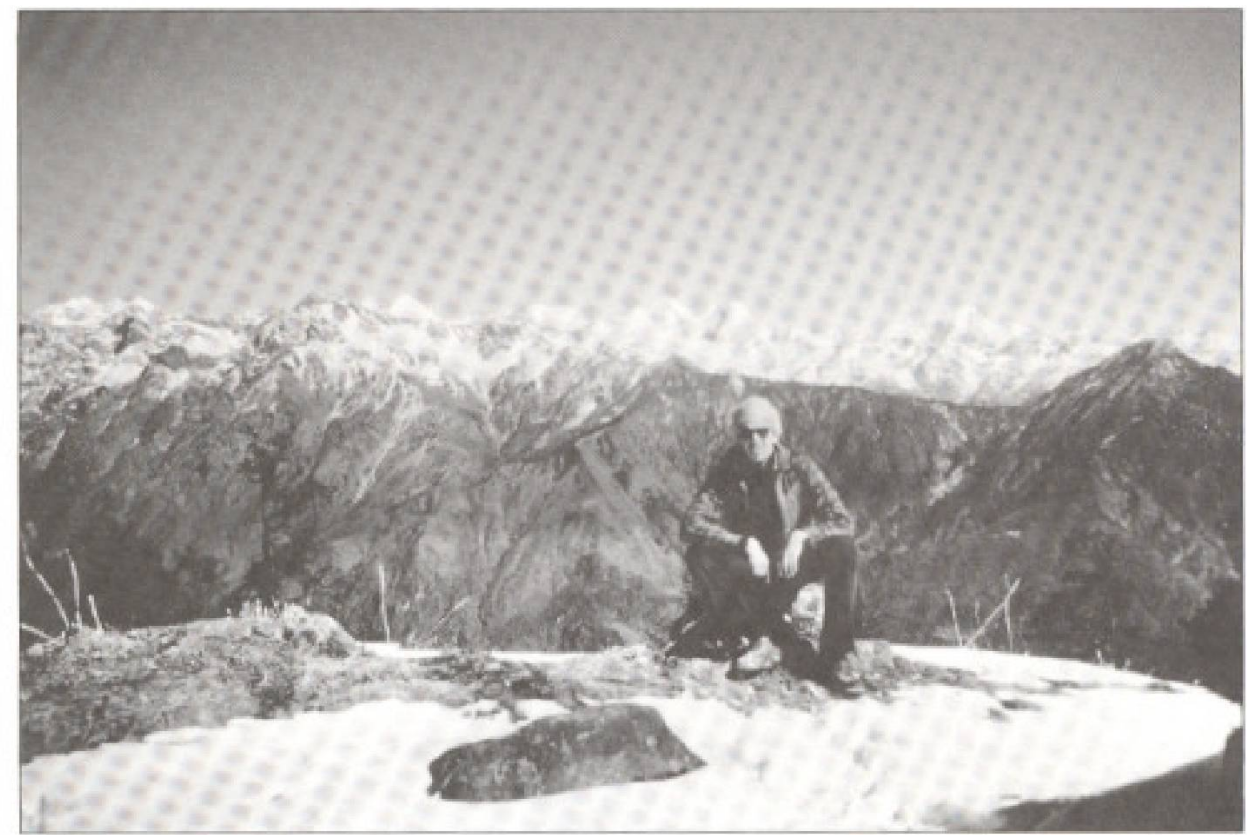

Club Aventure.



Adventure travel in Canada has become one of the nation's fastest growingsegmentsoftheoutdoor tourism market. Businesses offering travel packages have tripled in the pastdecade(Tourism Canada, 1993a). This situation is particularly pronounced in Western Canada where there has been a virtual explosion in the development of organizations offering adventure products and services to a growing number of domestic and international visitors (Tourism Research Group, 1992).

With its renowned natural and cultural resource base, Western Canada is well positioned to apitalize on the growing demand for adventure travel. However there are numerous challenges to address before this opportunitycan befullyrealized. Not the least of these issues relates to understanding the characteristics of the industry, as well as the nature of its markets and productrequirements (Reid and Smith, 1993). With this intelligence, the chances of strategically developing and marketing a truly competitive adventure travel product in Western Canada will be increased substantially.

\section{Adventure Travel : From Concept to Definition}

What is offered as adventure tourism in many parts of Western Canada has been variously described in the academic and professional literature as a curious and often confusing combination of outdoor recreation, ecotourism, and nature based travel (Maclaren Plansearch and al., 1988). Often little rationale exists for decisions on the labeling of these travel experiences (Robbins, 1993). Recently, studies have suggested dassifying adventure tourism products into as many as seven product categories (e.g. travel involving specific types of activities, geographic regions, learning experiences, etc.) with up to 21 different product dimensions (e.g. specific motivations, skill and technological requirements, travel party and cost characteristics) (Dube, 1994). While such approaches provide a potentially more systematicand focused basis for strategically managing the development of the industry as a whole, there is a real concern that many 
of these product typologies lack an operational focus for most industry businesses and potential markets.

For the purposes of this paper, the definitions used by the Adventure Travel Society and Tourism Canada will be applied. This is :

\section{[...] an outdoor leisure activity that takes place in an unusual, exotic, remote or wilderness destination, indolvessome form of transportation, and tends to be associated with bigh level of activity from which indi- viduals draw personal satisfaction from some unusualsigbt, activityor accomplisbment. (Tourism Canada, 1993a)}

There is obvious subjectivity with respect to what is or is not included with this definition. Adventure activities may range from those which are extremely rigorous (e.g. mountain climbing) to those which are less physically demanding (e.g. river rafting). Operators frequentlydifferentiate between bard and soft adventure based on such factors as geographical focus and physical skill requirements) but these distinctions are often a matter of personal interpretation... Similarly, inclusion of some resource consumptive pursuits such as hunting and fishing creates considerable controversy amongst industry analysts ${ }^{(1)}$.

As many as twelve different activity based adventure tourism product types have been identified in Western Canada (Tourism Canada, 1993b). Each has its own market and resource requirements. The critical point is that it is difficult to generalize about the characteristics of adventure tourism, given its wide ranging inclusions. Nonetheless, there are some commonalties which characterize the current status and future challenges of the industry from marketing and product development perspectives.

\section{Industry Characteristics}

While growing rapidly (approximately 15 $\%$ annuallyover the past 5 years), adventure tourism issmall in terms of both number of operators and contributions to the region's revenues (Tourism Canada, 1993a). Past research suggests that there are approximately 360 adventures operators in Western Canada, contributing between 2 $\%$ and $5 \%$ of the region's total tourism revenues (Alberta Tourism, 1992). On an individual business basis, the economic per formance of these operations is spotty some companies are doing exceptionally well, while many survive from season to season or trip to trip (Tourism Research Group, 1992). With theexception of British Columbia, which offers a full range of adventure products, one or two activities dominate the product lines of adventure tourism in Western Canada. For instance, canoeing and river rafting are the hallmark product lines in Yukon, while trail riding and guest ranch visiting are premier adventure products in Alberta (Table 1). This description focuses primarily adventure businesses primarily suited to serving long haul travel markets.

In combination, these businesses comprise an estimated $65 \%$ of all adventure tourism businesses in Canada. Over the years they have managed to position Western Canada as theadventure travel destination of choice for a good proportion of the nation's long haul travel markets (Tourism Canada Long Haul Pleasure Travel Market Studies, 1986-1991, U.S. Pleasure Travel Study, 1991). However, despite their relatively recent and growing significance they face many challenges from a marketing and product development perspective.

Most adventure operations in Western Canada can becharacterized as small, poorly capitalized, locally focused, seasonal businesses, experiencing high levels of business and labour turnover. While intrigued with catering to potentially lucrative international and other long haul travel segments, for the most part their exposure and success with such markets is limited. They generally do not have the comprehensive product offerings on-site suited to meeting the ever increasing demands of the marketplace. Similarly, fow have marketing alliances which give them a clear presence in international marketplaces.

In combination, these traits describe a relatively young and immature industry which requires substantial structural enhancement for it to survive and flourish in the international marketplace. In recent years a few larger companies haveemerged, and this has forced some rationalization and cooperative activity amongst a small but growing number of adventure tourism operators (Wild, 1993). The success of theseinitiatives has catalyzed a new level of energy and commitment to creating a truly competitive and export ready adventure travel industry for Western Canada.

\section{Marketing Issues and Strategies}

While the market for adventure travel in Western Canada is developing rapidly, there are some strategic marketing issues which must be addressed in order for the industry to realize its full potential. These issues relate to research and integrated marketing.

\section{Research}

Penetration into international markets by adventure suppliers is currently relatively low. Sectorally based industry research suggests that perhaps only nature observation, heli-skiing and heli-hiking attract more than half of their visitors from American and overseas origins (Tourism Canada, 1993). Furthermore, operator appreciation of the requirements of those markets with respect to such factors as trip planning, product preference, packaging, activity programming characteristics and sales distribution channels is often limited to haphazard personal exposure to visitor comments. This makes development of long haul markets for Western Canada's operators problematic, at best.

Critical to a greater and more sustainable market development is a fuller understanding of the size and behaviour of potential markets, how they can be attracted, and what must be done to ensure their adventure travel expectations aremet. While recent work in this area for some key origin markets for Canada has been conducted, more detailed work is needed to clearly understand the critical combinations of product attributes and benefits that these markets are seeking. This perspective is based on the belief that benefits which people seek in consuming a given product are the basic reasons for the existence of market segments and a re better determinants of behavior than are other approaches (Loker and Perdue, 1992). Findings emanating from benefit segmentation research by others (Dybka, 1987; Shoemaker, 1989) clearly supports this position.

In the case of adventure tourism, it is important to recognize that the operators are not experts in market research and analysis. They are experts in delivering 
TABLE 1

Estimated range, number and geographic distribution of adventure tourism operations in Western Canada

\begin{tabular}{|c|c|c|c|c|c|}
\hline Activity & British Columbia & Alberta & Saskatchewan & Yukon & Overall \\
\hline Nature/Photo Safaris & 27 & 9 & 2 & 22 & 60 \\
\hline Canoe/Kayak & 11 & 4 & 37 & 22 & 74 \\
\hline Bicycle & 2 & 4 & 9 & 2 & 17 \\
\hline Snowmobile/Dogsledding & 3 & 1 & 2 & 16 & 22 \\
\hline Snowshoeing/Ski Treking & 3 & 4 & 1 & 5 & 13 \\
\hline Hiking/Backpacking & 9 & 11 & 2 & 25 & 47 \\
\hline Sailing & 19 & 1 & 1 & 5 & 26 \\
\hline Rafting & 9 & 1 & 0 & 12 & 22 \\
\hline Pack/Wagon Trips & 13 & 30 & 1 & 8 & 52 \\
\hline Mountaineering/Climbing & 3 & 7 & 0 & 3 & 13 \\
\hline Heli Skiing/Hiking & 6 & 3 & 0 & 1 & 10 \\
\hline Scuba & 2 & 0 & 0 & 0 & 2 \\
\hline TOTAL: & 107 & 75 & 55 & 121 & 358 \\
\hline
\end{tabular}

Source: Tourism Canada, 1993a.

product linesin which they have developed specialization. In most cases, they are able to adjust somedimensions of their product offerings (e.g. accommodation, food requirements, physical activity requirements) to the on-site needs of a variety of markets as long as they are aware of the customer's requirements. Intuition suggests that there may be wide gaps in the benefits and product attributes sought by mountain climbersand trekkers as opposed to bird watchers and naturephotographers. However, if operators are not awate of these distinctions it is difficult for them to adjust their product appropriately.

As an example adventure travelers from West Germany tend to fall into two different segments (nature/culture and outdoors sports). Theculture/nature group represent about $17 \%$ of the country's long haul travelers. They are particularly interested in experiencing rurally based community life and its cultural artifacts as part of their comparatively soft adventure travel tonatural areas. Conversely, outdoor/ sportadventure enthusiasts comprise $10 \%$ of the overall West German travel market. They tend to be moreinterested in pursuing pbysially testing wilderness and outdoor pursuits. While both represent significant adventure travel segments from the same country, they have distinctive product requirements. Adventure travel operators failing to recognize these differences have a serious disadvantage when attempting to provide a first class adventure experience which matches with the needs of the marketplace (Table 2).

In a domestic context, Causal, Committed and Expert adventurers have been identified, each with their own distinctive traits (Angus Reid, 1992). Similarly, United States adventure travellers have been categorized as Outdoor Recreation, Resort and Nature/Culture travellers (Tourism Canada, 1990). All of these adventure travel segments express varying degrees of interest in Western Canada destinations.

This information is good general knowledge for adventure travel operators to understand, but it isoften toogeneralized for more than cursory use. In most cases it does not lead them to specific product or market refinement responses.

The industry requires benefit and attribute research which clearly defines not only what the specific product requirements of each adventure travel market segment are, but also theareas where these requirements overlap with those ofother adventure travel market segments... Armed with such intelligence it will then be in a more practical position to discern the potential for cooperative or consortia relationships between complementary industry partners in delivering the product required. This has already happened to a large extent within Canada's ski industry, through its benefits-based approach to research (Williams and Basford, 1992).

\section{Cooperative Marketing}

Western Canada's adventure tourism proponents express considerableoptimism about the growth potential of European long haul markets in particular. The vast expanses of relatively uninhabited, unspoiled wilderness are of great appeal to Europeanswhoselandscapehas been tamed for centuries. Origin markets from Germany, the United Kingdom, and France exhibit particularlystrong affinities for adventure travel. Together, these markets generate in excess of 1.3 million outbound adventure travel trips annually. However, the reality is that Canada currently captures only a small portion of these trips.

Many adventure travel operators in Western Canada have strong family ties with Europe. As a consequence, they havetended to market their products and services back to these country origins. For the most part their efforts have been promising but not particularly dramatic. This is largely because on an individual basis, most of them have only limited financial capacity to effectively market beyond their home regionon anon-going basis. Thisconstraint is particularly challenging, since it is generally accepted that the European market is extremely difficult to penetrate, 
without a sustained and comprehensive strategy. Notwithstanding this situation, Europe exhibits considerable potential in terms of its ability to generate longer stays, considerable destination and product loyalty, and significantly higher revenues foradventureoperators. German visitation in Alberta alone approximated 90,000 person visits in 1993, an estimated growth of $30 \%$ in a singleyear (Alberta Economic Development and Tourism, 1994).

The overriding challenge for Western Canada's adventure tourism industry is to penetrate the European market in a concerted and coordinated fashion. This can not be done on a piecemeal basis, yet adventure tourism operators in Western Canada have no formal organization of their own to execute this task. While sector specificassociations exist (e.g. River Rafting, Guides and Outfitters, Trail Riding, etc), there is no all encompassing organization which facilitates the sharing of marketing information, assists in the development of new products, encourages all inclusive product development or strategic marketing initiatives amongst complementary and non-competing businesses.

Coincidentally, little integration exists within most of the specific adventure tourism sector either. Only a few relatively recent integrated marketing programs have been oonducted by a selectgroup of package and ground operators. As in other jurisdictions, they are just beginning to recognize the market demand for multiactivity or catalogue type group or FTT tour programs. The industry must encourage the development of strategic alliances amongstits own members and government partners. It is only through this approach that the necessary marketing and financial resources can be leveraged to allow the industry to become a prominent force in the long haul pleasure travel markets of Europe and elsewhere.

\section{Product Issues and Strategies}

The strategic challenges associated with building adventure tourism in Western Canada are linked closely to issues of natural resoutce protection, product diversification, and human resourcedevelopment.

\section{Natural Resource Protection}

Western Canada is particularly endowed with the natural resources needed to form

TABLE 2

Adventure long haul pleasure traveller characteristics: West Germany, 1989

\section{CULTURE AND NATURE}

Primary Benefit

Adventure

\section{Market Share and Size}

$17 \%$ of long haul travel

Travel Philosophy

Guarded independent

Affirmed package

Preferred Product Attributes

Historic sites/cities

Museuns/galleries

Different cultures

Sightseeing smaller towns and villages

Outstanding scenery

Wide open spaces

Wildlife nature

\section{Demographic Profile}

Females $(51 \%)$

Younger (18-34)

Single

Upseale

\section{OUTDOOR SPORTS}

Primary Benefit

Adventure

\author{
Market Share and Size \\ $10 \%$ of long haul travel \\ Travel Philosophy \\ Enthusiastic independent
}

Preferred Product Attributes
Campgrounds/trailer parks
Fishing/hunting
Wildlife
Wilderness/nature
National parks
Outstanding scenery
Outdoor activities

Demographic Profile

Males (68\%)

Younger (under 35)

Single

Source: Pleasure Travel Markets to North America: Wese Germany, 1989, ISTC-Tourism, Octoher, 1989.

the critical core of an internationally competitive set of adventure travel products. Its outstanding scenery e.g. mountains, rivers and lakes, coastlines and tundra, wildlife population and pristine wilderness afford a strong base for product development. The existence and growth of the adventure travel industry is critically linked to the maintenance and integrity of this resource base (ARA et al,, 1991).

Domestic and international markets recognize Western Canada's natural resource base as an asset of appreciating value. They areprepared to pay handsomely for the opportunity to experience it. Daily rates for the less exotic adventure excursions (e.g. rafting, canoeing, cycling, mountain biking, trail riding, and hiking excursions) are not onerous and average in the range of $\$ 100$ per day. More unusual adventure tourism experiences(e.g.guided photography or painting, mountain climbing, helihiking trips to particularly remote locations, etc.), can cost as much as $\$ 1,000$ per day. Typically, these trips are exclusive of transportation to the point of the on-site excursion.

However, Western Canada's competitive natural resource advantage is vulnerable to a variety of challenges. Adventure tourism is inscreasingly faced with issues of resource scarcity, security, and competition (ARA, 1993). From an internal perspective, the adventure tourism operators must take concerted steps to protect the natural environment and practice sustainable resource use(Hawkes and Williams, 1993). Externally, the adventure tourism industry as a whole must play a stronger role in guiding provincial and federal governments toward fair and equitable solutions to sharing and conserving Western Canada's natural resources. Promising strides have commenced in that direction through the 
creation of such organizations as British Columbia's Council of Tourism Associations (which includes adventure tourism representation). This advocacy organization provides focused policy inputs into government based integrated strategicland use planning processes, commercial back country recreation policies, protected areas strategies, and forest practices codes, that are now being formulated in British Columbia.

\section{Product Integration}

While Western Canada's adventure tourism product core (the natural resource base) is particularly strong, the all important peripherals that produce the valueadded necessary to bring travelers to the region are as yet not fully developed or understood. In general terms these include top quality accommodation facilities, reliable transportation equipment, as well as nature and culture based travel packages and programs.

Currently, Western Canada's adventure tourism products lack the diversity and comprehensiveness needed to effectively serve most long haul markets. This is largely due to a curious mix of individual entrepreneurialism (which keeps many operators focused on their own product out of a love for that activity to the exclusion of broader interests), a limited appreciation of the wide range of facilities and services required to compete effectively at an international level, and a relatively early stage in the ewolution of the sector.

Most operators are focused on the day to day operation of their own businesses. As such, they are unlikely to form consortia with other operators unless there are very compelling reasons. Appealing rationales include enhanced abilities to expand the range of product offerings available, penetrate larger and growing markets on a more sustained basis, share marketing and sales costs, as well as expand and stabilize business revenues without significantly greater financial commitments.

A particularly promising application of integrated product development currently evolving in Western Canada involves the creation of adventure touriom detination regroms. Examples of these include Whister, B.C., and to a more limited extent Banff and Kananaskis Countryin Alberta. These destinations are gradually building a very diversified rangeofadventuretravel product lines. Using the notion of base camping (Rubin and Gorman, 1993) as the fundamental integrating strategy, these destinations provide a full rangeofamenities and facilities typically sought by resort users, but package a wide spectrum of adventure experiences with the base camp offerings. Particularly unique adventure tourism components are provided by specialized adventure tourism operators working in conjunction with the adventure destination base camp. They are linked together via integrated reservation systems and cooperative marketing agreements (WRA, 1994). Customers perceive the resort destination as being managed by a single entity, but in actual fact it is operated by a consortia of specialized companies working with a common commitment to provide a full adventure tourism experience.

While such approaches to integrated product development are emerging in some parts of Western Canada, for the most part they are few in number and early in their evolution. Astrategicopportunity exists to develop the base amp model in many parts of the region.

Initiatives proposed by someof the potential integrator organizations such as Western Economic Diversification or Canadian Heritage could foster further development of this model.

\section{Product Diversification}

While the owtdowr component of adventure tourism is well recognized in Western Canada, significant opportunity exists to diversify product lines by capitalizing on the sofferdimensions of adventure travel. A growing proportion oflong haul adventure travellers express an interest in incorporating a cultural component into their experiences (Tourism British Columbia, 1992). Thiscan be done through the development of sensitive interpretation of ethnic and aboriginal cultures. An emerging opportunity of particular note involves linkages with aboriginal tourism operators. The richness of Western Canada's aboriginal culture and its strong links to the wilderness landscape where so much of adventure tourism occurs affords exciting potential for integrating soft dimensions of adventure into the regions product portfolio. In B.C. alone numerous native groups, have developed in excess of
182 different aboriginal tourism businesses (Johnston, 1993).

First Nations people in Western Canada are working diligently to develop both adventure tourism products and services suited to the creation of a fuller adventure travel experience. The Canadian National Aboriginal Tourism Association, a newly formed association of aboriginal tourism operators, is attempting to expand the range and quality of a boriginal tourism products. They are particularly focusing on development activities which respect the dignity of First Nations People (CNATA, 1993). Their efforts hold promise for additional authentic cultural products complementary to adventure tourism.

\section{Human Resource Development}

Human resource development has traditionally not been the watchword of the adventure tourism industry in Western Canada. The majority of employees are seasonal and are drawn to their jobs by their love for the activity. The concept of investing in the training of such employees, beyond the basics has notbeen a top priority for mostoperations. This is largely because of the limited amount of time and resources available for such activities, and the perceived risk that such investuments would be lost in the annual turnover of seasonal employees.

However, as the adventure travel industry continues to grow, so will the need for more professionalism in the delivery of the travel product (Mitchell, 1992). Pushed by the demands of ever more sophisticated and experienced customers, safery and liability insurance concerns, and growing consumer awareness of environmental issues, adventure tourism operators will of necessity be forced to become proactive in the development of their employees. As a group they will have to clearly identify the range of skills and competencies that current and new entrants to the industry should have in order to become proficient employees(Glencross, 1993). Furthermore theywill have toactively pursuecost efficient and timely means of delivering such training and education programs. Already these strategies are beginning toemergethrough the developmentofoccupational standards for outdoor guides (TISCC, 1993) and college based adventure tourism programs (Youds, 1994). 
The rationale for these initial training initiatives is to develop personnel with targeted occupational capabilities that are transferable across a range of adventure tourism operations. In this manner those employees who fail to remain with a particular operation in succeeding seasons, may work within the sector at other locations, thereby still contributing to the overall quality of service and professionalism of the adventure tourism industry.

\section{Conclusions}

Adventure tourism in Western Canada exhibits considerable potential as a contributor to the region's economic, social and cultural fabric. Currently it is characterized as being primarily managed in an entrepreneurial mode by many small lifestyle operators, who want to pursue their own product specific adventure activities. For the most part the industry's success in recent years has been based on its ability to capitalize on the region's world class natural heritage. While it has been able to capture a portion of the expanding world demand for adventure tourism, its future growth and competitiveness will be dependent to a very large extent on how well it is able to harness the combined ingenuity and resources of its members. This cooperation and integration will be needed to adequately address several emerging and potentially critical product development and marketing issues (Wild, 1993). The adventure tourism industry's ability to meet these challenges will be predicated on a shift from a primarily entrepreneurial and individualistic mode of operation to a more structured and cooperative approach. $f$

\section{REFERENCES AND NOTE}

ALBERTA TOURISM, Strategic Marketing Plan for Tourism to Alberta, 1991-1996, Edmonton. Alberta Tourism, 1991

ANG US REID GROUP, The Canadian Pleasure Travel Market Segmentation Study: Outbound Travel, Toronto, Angus Fieid, 1992.

ARA, ETHOSAND BIOQUEST, The Tourism Resource Council: A Mechanism for Representing the Tourism Industry's Interests on Natural Resource Management, Ottawa, Industry. Science and Technology Canada, 1991.

ARA, Tourism Industry's Ressource Management Needs: Final Report, Victoria, B.C. Ministry of Tourian, 1953.

B.C. MINISTAY of TOUAISM, A Vision for Tourism, Victoria, B.C., 1992.

CNATA, Business Plan: Canadian National Aboriginal Tourism Association, Ottawa, Canadian National Aboriginal Tourism Association, 1990
DPA, MACLAREN PLANSEARCH, Flshing Lodges and Resorts in British Columbia: Marketing and Development Initiatives, Victoria, B.C. Miristry of Tourism and Provincial Secretary, 1988.

DPA, Strategic Plan for the Guide Outfitters of British Columbla, Ottawa, Industry. Science and Technology Canada, 1991.

DUBE, R. Adventure Travel Fedefined: Product Differentiation and Segmentation of Chents and Markets, in Staite, M.J. and R.A. Wong (eds), Regional Marketing Partnerships and Adventure Tourism, TTRA Canada and Naw England Chapters Joint Conference Proceedings, Fortland, Maine, 1993, pp. 81-86.

OYBKA, J, A Look at the American Trawler: The U.S Plegsure Travel Market Study, Journal of Travel Research, 25[3]. 1987, pp. 24.

GLENCROSS, $P$., Developing the Organization: Forma. tion of the Nova Scotig Adventure Touriem Assochation (WSATAY, in Staite, M.J. and A.A. Wong (eds). Regional Marketing Partnorships and Adventure Tourism, TTRA Canada and Now England Chapters Joint Conference Proceedings, Fortland, Maine, 1993, pp. 88-96.

HAWKES, S. and P.W. WILLIAMS, The Greening of Tourtsm: From Principles to Practice: A Casebook of Best Environmental Practice in Tourism, Burnaby. Simon Fraser University. Centre for Tourism Policy and Pesearch, 1993.

JOHNSTON, G. First Nations Tourism Products in British Columbia, Victoria, B.C. Miristry of Tourism and Ministry Responsible for Culture, 1993.

LOKER, L.E. and R.R. PERDUE, A Benefit Based Segmentation of a Manresident Summer Travel Market, Journal of Travel Research, 31/11. 1992. pp. $30-35$.

MACLAREN PLANSEARCH. ETHOS CONSULTING. TOURISM RESEARCH GROUP, Adventure Travel in Western Canada: Product Development Stratogy. Ottawa. Tourism Ca. nada, volume $1,1980$.

MITCHELL, B J Tourism the Professional Challenge: A Framework for Actlon, Vancouver, Pacific Rim Institute of Tourism, 1992.

REID. L.J.N. and S.L.J. SMITH, Research and Action Agenda: Aegional Marketing Partnerships and' Adventure Travel, in Staite, M.J. and F.A. Wong (eds), Ragional Marketing Partnorships and Adventure Tourism, TTRA Canada and Now England Chapters Joint Conference Procesdings, Portland, Maine, 1993, pp. 104 106.

AOBBINS, M.J., Strategric Directions for the 1990 's: The Spectalty Outdoors Sector in Ontario, in Staite. M.J. and R.A. Wong leds), Rogional Markoting Partnerships and Adventure Tourism. TTRA Canada and New England Chapters Joint Confer encé Proceedings, Portland, Maine, 1993. pp. 53-61.

AUEIN, M.S. and R. GOAMAN, Feinventing Leisure, Urban Land, February 1993, pp. 20-31.

SHOEMAKER, S., Segmentation of the Senior Pleasure Travel Market, Journal of Travel Research, $27(3)$. 1969 . pp. 14-21.

TISCC, National Occupational Standards - Outdoor Guide [Core Skills]. Ottawa, Tourism Industry Standards and Certification Committee, 1993.

TOUFIS M CANADA, 1989 U.S. Pleasure TrawelMarket - Canada's Progress and Challenges: Highlights Report, Ottawa, ISTC-Tourism, Nowember 1990. TOUAISM CANADA, B.O.S.S."Tourism Database, Ottawa, Industry Canada-Tourism Canada, 1993b.

TOUAISM CANADA, Market and Development Potential for Adventure Travel in Canada: A Position Report, Ottawa, Industry CanadaTourism Canada, Canada Directorate, 1993a.

TOURISM CANADA, Pleasure Travol Markets to North America: West Germany - 1989, Ottawa, ISTCTourism, 1989.
TOUAISM RESEARCH GAOUP, Tourism in British Columbia: A Status Report, Victoria B.C. Ministry of Tourism, 1992.

WHISTLER RESORT ASSOCIATION, Whistler Resort Association 1993 Annual Report, Whistler, B, C. 1994

WILD, C. Trends in the Adventure Travel Industry, in Staite, M.J. and R.A. Wong (eds), Regional Markating Partnarships and Adventure Tourism, TTRA Canada and Now England Chapters Joint Conference Proceedings. Portland, Maine, 1999, pp, 40-52.

WILLIAMS, PW. and R. BASFORD, Segmenting Downhill Sking's Latent Demand Markets. American Behavioural Scientist, 36/2), 1992, pp. 222235 .

YOUDS, M., Adventure Tourism Program Drawing Wridwide Attention, Kamloops Daily New. Kamloops, British Columbia, A1, A4, 1994.

(1) To correspond with the previously mentioned definition of adventure tourism, this paper excludes diseussion of hunting and fishing adventure activities despite their very significant role as generators of tourism revenues in Western Canada (DPA 1991; DPA and Maclinen, 1968\%. 